Julista Mustamu, Diskresi dan Tanggungjawab.

\title{
DISKRESI DAN TANGGUNGJAWAB ADMINISTRASI PEMERINTAHAN
}

\author{
Oleh : Julista. Mustamu
}

\begin{abstract}
In a modern State law (Welfare State), granting discretion to government is inevitable as the weaknesses or limitations of legislation and in accordance with the dynamic activities of the government in performing public services in the community is growing rapidly. The use of discretion should not be freely, in the sense that must not conflict with the general principles of good governance and should not be contrary to public interest.

Keywords: Government, Authority discretion

\section{A. LATAR BELAKANG.}

Didalam

menjalankan pemerintahan, Pemerintah telah dilengkapi dengan kewenangan-kewenangan baik yang bersifat atributif maupun yang bersifat delegatif. Dengan adanya perkembangan masyarakat, maka seringkali terdapat keadaan-keadaan tertentu yang sifatnya mendesak yang membuat Pejabat/Badan`Administrasi pemerintahan tidak dapat menggunakan kewenangannya khususnya kewenangan yang bersifat terikat (gebonden bevoegheid) dalam melakukan tindakan hukum dan tindakan faktual secara normal.

Sebagai Negara yang bertujuan untuk memajukan kesejahteraan umum, melekatnya fungsi memajukan kesejahteraan umum dalam welfare state (Negara kesejahteraan) menimbulkan beberapa konsekuensi terhadap penyelenggaraan pemerintahan yaitu pemerintah harus berperan aktif mencampuri bidang kehidupan social ekonomi masyarakat. Untuk itu kepada pemerintah dilimpahkan tanggung jawab bestuurszorg atau public service.

Agar servis publik dapat dilaksanakan dan mencapai hasil maksimal,

kemerdekaan tertentu untuk bertindak atas inisiatif sendiri menyelesaikan berbagai permasalahan pelik yang membutuhkan penanganan secara cepat, sementara terhadap permasalahan itu tidak ada, atau masih belum dibentuk suatu dasar hukum penyelesaiannya oleh lembaga legislative yang kemudian dalam hukum administrasi diberikan kewenangan bebas berupa diskresi (S.F.Marbun 2001:73).

\section{Menurut Marcus}

Lukman sebagaimana dikutip oleh Saut $P$ Panjaitan (S.F.Marbun 2001 : 17) mengatakan bahwa persoalan-persoalan penting yang mendesak, sekurang-kurangnya mengandung unsurunsur sebagai berikut:

a. Persoalan-persoalan yang muncul harus menyangkut kepentingan umum, yaitu kepentingan bangsa dan negara, kepentingan masyarakat luas, kepentingan rakyat banyak/bersama, serta kepentingan pembangunan.

b. Munculnya persoalan tersebut secara tibatiba, berada diluar rencana yang telah ditentukan.

c. Untuk menyelesaikan persoalan tersebut, peraturan perundang-undangan belum mengaturnya atau hanya mengatur secara umum, sehingga administrasi Negara mempunyai kebebasan untuk menyelesaikan atas inisiatif sendiri.

d. Prosedurnya tidak dapat diselesaikan menurut administrasi yang normal, atau jika diselesaikan menurut prosedur
\end{abstract} kepada administrasi Negara diberikan suatu 
administrasi yang normal justru kurang berdaya guna dan berhasil guna.

Dengan adanya kewenangan diskresi ini berarti bahwa sebagian kekuasaan yang dipegang oleh badan pembentuk undangundang dipindahkan kedalam tangan pemerintah/administrasi Negara sebagai badan eksekutif. Jadi supremasi badan legislative diganti pleh supremasi badan eksekutif (Siti Soetami, 2000:46), karena administrasi Negara melakukan pennyelesaian masalah tanpa harus menunggu perubahan Undang-Undang dari bidang legislatif (Diana Halim

Koentjoro,2004:42). Hal tersebut karena pada prinsipnya Badan/Pejabat administrasi pemerintahan tidak boleh menolak untuk memberikan pelayanan kepada masyarakat dengan alas an hukumnya tidak ada ataupun hukumnya ada tetapi tidak jelas, sepanjang hal tersebut masih menjadi kewenangannya.

Sebagai bagian dalam penyelenggaraan tugas-tugas pemerintahan dan pelayanan kepada masyarakat, kewenangan pembuatan kebijakan melekat pada jabatan pemerintahan (inherent aan het bestuur) yang dijalankan oleh pejabat pemerintahan, dan ternyata telah menyebabkan banyak pejabat yang menjadi tersangka bahkan terpidana. Disisi lain, dianut suatu pendapat bahwa kebijakan pemerintah itu tidak dapat dipersoalkan secara hukum. Arifin P. Soeria Atmadja mengatakan, "suatu kebijakan tidak mungkin diajukan kepengadilan apalagi dikenakan hukum pidana karena dasar hukum kebijakan yang akan menjadi dasar hukum penuntutannya tidak ada. Hal ini disebabkan suatu kebijakan pada umumnya berjalan tidak seiring atau belum diatur dalam peraturan perundangundangan" (Arifin $\mathrm{P}$ Soeria Atmadja:2008:198).

Menurut Hadjon, bahwa kebijakan penguasa tidak dapat digugat didasarkan pada prinsip "beleidsvrijheid" yang ada pada penguasa. Beleidsvrijhneid penguasa meliputi; tugas-tugas militer, politonil, hubungan luar negeri, pekerjaan untuk kepentingan umum, keadaan yang tidak dapat diduga terlebih dahulu atau dalam mengambil tindakan darurat (Philipus M Hadjon:2007:119). Sementara Amarullah Salim (1994:157-158) mengatakan bahwa perbuatan kebijakan penguasa tidak termasuk kompetensi pengadilan untuk menilai sesuai dengan yurisprudensi dan ilmu hukum.

Jika dikatakan bahwa kebijakan pemerintah tidak dapat dipersoalkan secara hukum, namun ternyata dalam praktek yang selama ini terjadi pembuat kebijakan diproses secara hukum dan ditetapkan sebagi tersangka bahkan terpidana. Hal ini menimbulkan pertanyaan Dalam hal apa tanggung jawab jabatan dan tanggung jawab pribadi diterapkan dalam kaitannya dengan kebijakan pemerintahan? Serta apakah ada batasan norma hukum yang dapat diterapkan terhadap kebijakan pemerintahan?

\section{B. PEMBAHASAN}

Menurut Kamus Hukum, Diskresi berarti kebebasan mengambil keputusan dalam setiap situasi yang dihadapi menurut pendapatnya sendiri. Sedangkan menurut Rancangan Undang-Undang Administrasi Pemerintahan Draft bulan Juli 2008 didalam pasal 6 mengartikan diskresi sebagai wewenang badan atau pejabat pemerintahan dan atau badan hukum lainnya yang memungkinkan untuk melakukan pilihan dalam mengambil tindakan hukum dan atau tindakan faktual dalam administrasi pemerintahan.

Ada beberapa pakar hukum yang memberikan definisi tentang diskresi, diantaranya: S. Prajudi Atmosudirjo (1994:82) yang mendefinisikan diskresi, discretion (Inggris), discretionair(Perancis), freies ermessen (Jerman) sebagai kebebasan bertindak atau mengambil keputusan dari para pejabat administrasi Negara yang berwenang dan berwajib menurut pendapat sendiri. 
Selanjutnya dijelaskan bahwa diskresi diperlukan sebagai pelengkap dari asas legalitas, yaitu asas hukum yang menyatakan bahwa setiap tindakan hukum yang menyatakan bahwa setiap tindak atau perbuatan administrasi Negara harus berdasarkan ketentuan Undang-Undang.

Akan tetapi tidak mungkin bagi UndangUndang untuk mengatur segala macam kasus posisi dalam praktek kehidupan sehari-hari. Oleh sebab itu perlu adanya kebebasan atau diskresi administrasi Negara yang terdiri atas diskresi bebas dan diskresi terikat. Pada diskresi bebas, UndangUndang hanya menetapkan batas-batas dan administrasi Negara bebas mengambil keputusan apa saja asalkan tidak melampaui/melanggar batas-batas tersebut, sedangkan pada diskresi terikat, UndangUndang menetapkan bebarapa alternatif keputusan dan administrasi Negara bebas memilih salah satu alternatif keputusan yang disediakan oleh Undang-Undang.

Indroharto (1993:99-101) menyebut wewenang diskresi sebagai wewenang fakultatif, yaitu wewenang yang tidak mewajibkan badan atau pejabat tata usaha Negara menerapkan wewenangnya, tetapi memberikan pilihan sekalipun hanya dalam hal-hal tertentu sebagaimana ditentukan dalam peraturan dasarnya. Sedangkan Sjachran Basah (1997:3) mengatakan bahwa freies ermessen adalah kebebasan untuk bertindak atas inisiatif sendiri, akan tetapi dalam pelaksanaannya haruslah tindakan-tindakan administrasi Negara itu sesuai dengan hukum, sebagaimana telah ditetapkan dalam Negara hukum berdasarkan Pancasila.

\section{Lebih lanjut Diana Halim}

Koentjoro (2004:41) mengartikan freies ermessen sebagai kemerdekaan bertindak administrasi Negara atau pemerintah (eksekutif) untuk menyelesaikan masalah yang timbul dalam keadaan kegentingan yang memaksa, dimana peraturan penyelesaian untuk masalah itu belum ada. Sedangkan Esmi Warassih (2005:138-139), mengatakan bahwa dalam rangka pelaksanaan kebijaksanaan publik, para birokrat dapat menentukan kebijaksanaannya sendiri untuk menyesuaikan dengan situasi dimana mereka berada, terutama di dalam mengimplementasikan suatu kebijaksanaan publik. Dengan adanya diskresi ini diharapkan agar dengan kondisi yang ada dapat dicapai suatu hasil atau tujuan yang maksimal.

Berdasarkan doktrin-doktrin hukum tersebut diatas, maka dapat disimpulkan bahwa pada hakekatnya diskresi merupakan kebebasan bertindak atau kebebasan mengambil keputusan dari Badan atau Pejabat administrasi pemerintahan menurut pendapatnya sendiri sebagai pelengkap dari asas legalitas manakala hukum yang berlaku tidak mampu menyelesaikan permasalahan tertentu yang muncul secara tiba-tiba, bias karena peraturannya memang tidak ada atau karena peraturan yang ada yang mengatur tentang sesuatu hal tidak jelas.

Asas Legalitas (legaliteitsbeginsel) dikenal dalam hukum pidana dan hukum islam, namun asas legalitas yang dimaksud dalamn tulisan ini adalah konteks Hukum administrasi, yakni het beginsel van wetmatigheid van bestuur atau asas keabsahan dalam pemerintahan.

Asas legalitas ini dianggap sebagai dasar terpenting dari Negara hukum (al seen van belangrijkste fundamentenvan de rechtsstaat) (L.J.A.Damen,et.al.2005:52), dan mengandung arti bahwa pemerintah hanya dapat melakukan tindakan berdasarkan kewenangan yang diberikan dan dibatasi oleh undang-undang, "het bestuur kan allen op basis van door de wet toegekende en afgebakende bovoegdheden handelen" (H.D.Stout:1994:33).

Meskipun asas legalitas itu dianggap sebagai prinsip terpenting dari Negara hukum, namun mendasarkan setiap tindakan pemerintahan dibidang publik pada asas legalitas atau hukum tertulis sebenarnya bukan tanpa masalah. Hal ini karena, menurut Bagir Manan, adanya cacat bawaan (natural 
defect) dan cacat buatan (artificial defect) dari peraturan perundangundangan sebagai suatu bentuk hukum tertulis.

Sebagai ketentuan tertulis (written rule) atau hukum tertulis (written law) peraturan perundang-undangan mempunyai jangkauan yang terbatas - sekedar moment opname dari unsur-unsur politik, ekonomi, social, budaya dan hankam yang paling berpengaruh pada saat pembentukan, karena itu mudah sekali bila dibandingkan dengan perubahan masyarakat yang semakin cepat atau dipercepat (Bagir Manan dan Kuntana Magnar, 1987:16).

Disamping itu, hal lain yang kerap munculkan masalah dalam penerapan asas legalitas adalah struktur norma hukum publik yang akan dijadikan dasar bagi tindakan pemerintahan. Berbeda dengan struktur norma hukum pidana atau perdata, struktur norma hukum publik khususnya Hukum Administrasi itu sifatnya berantai dan bertingkat. Artinya terhadap suatu urusan pemerintahan itu normanya tidak hanya terdapat dalam suatu undang-undang atau peraturan daerah tetapi bertebaran dalam berbagai peraturan perundangundangan. Seorang pejabat yang akan melakukan tindakan hukum tertentu dituntut untuk mengkaji semua peraturan perundangundangan terkait.

Guna mengantisipasi persoalan tersebut kepada pemerintah diberikan freies Ermessen atau diskresi, yakni kemerdekaan pemerintah untuk dapat bertindak atas inisiatif sendiri dalam menyelesaikan persoalanpersoalan social (E. Utrecht, 1988:30). Dengan kata lain, freies Ermessen merupakan salah satu sarana yang memberikan ruang bergerak bagi pejabat atau badan-badan administrasi Negara untuk melakukan tindakan tanpa harus terikat sepenuhnya pada undang-undang (Markus Lukman,1996:205).

Ketika freies ermessen atau diskresi ini dituangkan dalam bentuk tertulis, ia menjadi peraturan kebijakan, yakni peraturan umum yang dikeluarkan oleh instansi pemerintahan berkenaan dengan pelaksanaan wewenang pemerintahan terhadap warga Negara atau terhadap instansi pemerintahan lainnya dan pembuatan peraturan tersebut tidak memiliki dasar yang tegas dalam UUD dan undangundang formal baik langsung maupun tidak langsung.

Artinya, peraturan kebijaksanaan tidak didasarkan pada kewenangan pembuatan undang-undang dan oleh karena itu tidak termasuk peraturan perundangundangan yang mengikat umum tetapi dilekatkan pada wewenang pemerintahan suatu organ administrasi Negara dan terkait dengan pelaksanaan kewenangannya (P.J.P.Tak, 1991:129). Dalam hal ini, peraturan kebijakan (beleidsregel) adalah sarana hukum tata usaha Negara yang bertujuan mendinamisir keberlakuan peraturan perundang-undangan (Laica Marzuki,1996:9).

\section{VALIDITAS DISKRESI DAN BATAS- BATAS PENGGUNAANNYA}

Adalah sesuatu yang tak bias dipungkiri bahwa pemberian diskresi kepada pemerintah merupakan sebuah kemestian, seiring dengan munculnya konsepsi Negara kesejahteraan (welfare state) menjelang perang dunia kedua, dan sejalan dengan kelemahan atau keterbatasan peraturan perundang-undangan sebagaimana disebutkan diatas, serta sesuai dengan dinamisnya kegiatan pemerintah dalam melaksanakan tugas pelayanan publik ditengah masyarakat yang berkembang pesat. Konsepsi Negara ini menempatkan pemerintah selaku pihak yang berkewajiban mewujudkan kesejahteraan social, yang dalam rangka itu pemerintah banyak terlibat dengan kehidupan ekonomi dan social warga Negara.

Meskipun pemberian diskresi kepada pemerintah itu merupakan kemestian dalam suatu Negara hukum, namun penggunaan diskresi itu bukan tanpa batas. Ramburambu dalam penggunaan diskresi dan pembuatan kebijakan pemerintah berdasarkan Hukum 
Administrasi Negara adalah Asas-Asas Umum Pemerintahan Yang Baik (AAUPB), khususnya asas larangan penyalahgunaan wewenang (detournement de pouvoir) dan asas larangan sewenang-wenang (willekeur). Dengan kata lain, kebijakan pemerintah akan dikategorikan sebagai kebijakan yang menyimpang jika didalamnya ada unsur sewenang-wenang. Selain itu kebijakan dianggap menyimpang jika bertentangan dengan kepentingan umum.

Ada tidaknya unsur penyalahgunaan wewenang diuji dengan asas spesialitas (specialiteitsbeginsel) yakni asas yang menentukan bahwa wewenang itu diberikan kepada organ pemerintahan dengan tujuan tertentu (L.J.A.Damen, 2005:57). Jika menyimpang dari tujuan diberikannya wewenang ini dianggap sebagai penyalahgunaan wewenang.

Unsur sewenang-wenang diuji dengan asas rasionalitas atau kepantasan (redelijk). Suatu kebijakan dikategorikan mengandung unsur willekeur jika kebijakan itu nyata-nyata tidak masuk akal atau tidak beralasan (kennelijk onredelijk).

Rancangan Undang-Undang

Administrasi Pemerintahan Draft bulan Juli 2008 dalam pasal 6 ayat (1) memberi batasan terhadap diskresi dengan menyebutkan bahwa Pejabat pemerintahan dan atau badan hukum lainnya yang menggunakan diskresi dalam mengambil keputusan wajib mempertimbangkan tujuan diskresi itu sendiri, peraturan perundangundangan yang menjadi dasar diskresi dan asas-asas umum pemerintahan yang baik. Selanjutnya ayat (2) dan ayat (3) menyebutkan bahwa penggunaan diskresi wajib dipertanggungjawabkan kepada pejabat atasannya dan masyarakat yang dirugikan akibat keputusan diskresi yang telah diambil serta dapat diuji melalui upaya administrative atau gugatan di Peradilan Tata Usaha Negara. Ketentuan tersebut berarti bahwa Rancangan Undang-Undang
Administrasi Pemerintahan ketentuan tersebut berarti bahwa Rancangan UndangUndang Administrasi Pemerintahan bukan hanya akan member batasas-batas penggunaan diskresi oleh Badan/Pejabat administrasi Pemerintah akan tetapi juga mengatur mengenai pertanggungjawaban Badan/Pejabat Administrasi Pemerintahan terhadap penggunaan diskresi yang tidak hanya bersifat pasif dalam arti menunggu adanya gugatan dari masyarakat melalui Pengadilan Tata Usaha Negara akan tetapi juga bersifat aktif dengan adanya kewajiban mempertanggungjawabkan penggunaan diskresi kepada Pejabat atasannya mengingat hal tersebut merupakan suatu kewajiban yang sifatnya melekat pada kewenangan yang menjadi dasar adanya diskresi itu sendiri. Tetapi yang disayangkan adalah meskipun Pasal 6 RUU Administrasi Pemerintahan telah mengatur tentang kewajiban melaporkan tindakan diskresi kepada atasan dalam bentuk tertulis dengan memberikan alas an-alasan pengambilan keputusan diskresi, namun apabila ketentuan tersebut tidak dilaksanakan tidak ada sanksinya sehingga hal tersebut dapat menyebabkan Badan/Pejabat Administrasi Pemerintahan yang menerbitkan keputusan diskresi berdalih bahwa keputusan yang diambilnya bukan keputusan diskresi ataupun berdalih ia tidak tahu bahwa keputusan yang diambilnya adalah keputusan diskresi.

Walaupun demikian paling tidak dengan akan dijadikannya batas-batas penggunaan diskresi sebagai suatu norma yang mengikat, maka hal tersebut sudah cukup untuk menghindari dilaksanakannya penyalahgunaan wewenang (detournement de pouvoir) dan perbuatan sewenangwenang (willekeur) oleh Badan/Pejabat Administrasi Pemerintahan, sebab tujuan utama dari normatifisasi adalah menciptakan dan menjadikan Hukum Administrasi Negara menunjang kepastian hukum yang member jaminan dan perlindungan hukum baik bagi 
warga Negara maupun administrasi Negara (Rusli K Iskandar dalam SF Marbun dkk, 2001:87).

Menurut Anna Erliyana, penggunaan freies ermessen oleh Badan/Pejabat administrasi Negara dimaksudkan untuk menyelesaikan persoalan-persoalan penting dan mendesak serta tiba-tiba yang sifatnya kumulatif. Bisa saja muncul persoalan yang penting tetapi tidak mendesak untuk segera diselesaikan. Ada pula kemungkinan muncul persoalan mendesak, tapi tidak terlalu penting untuk diselesaikan. Suatu persoalan baru dapat dikualifikasi sebagai persoalan penting apabila persoalan tersebut menyangkut kepentingan umum, sedangkan criteria kepentingan umum harus ditetapkan oleh suatu peraturan perundang-undangan (Anna Erliyana, 2005:138).

Berdasarkan hal tersebut diatas dapat disimpulkan bahwa penggunaan kewenangan diskresi oleh Badan/Pejabat administrasi pemerintahan hanya dapat dilakukan dalam hal tertentu dimana peraturan perundangundangan yang berlaku tidak mengaturnya atau karena peraturan yang ada yang mengatur tentang sesuatu hal tidak jelas dan hal tersebut dilakukan dalam keadaan darurat/mendesak demi kepentingan umum yang telah ditetapkan dalam suatu peraturan perundangundangan.

\section{TANGGUNGJAWAB PEMERINTAHAN}

Untuk mengetahui siapa yang bertanggung jawab dalam penyelenggaraan tugas-tugas pemerintahan dan pelayanan kepada masyarakat, terlebih dahulu perlu dikemukakan tentang jabatan pemerintahan yang dilekati fungsi dan kewenangan pemerintahan.

Logemann mengatakan bahwa Negara dan organisasi jabatan "de staat is ambtenorganisatie" (Logemann, 1854:88) dan dalam suatu Negara itu ada jabatan pemerintahan, yakni lingkungan pekerjaan tetap yang dilekati dengan wewenang untuk menyelenggarakan urusan pemerintahan, yakni semua tugas-tugas kenegaraan selain bidang pembuatan undang-undang dan peradilan,"elke werkzaamheid van de overhead, welke niet als wetgwving of als rechtspraak is aan te merken"

(C.J.N.Versteden,1984:13).

Tugas dan wewenang yang melekat pada jabatan ini dijalankan oleh manusia (natuurlijke persoon), yang bertindak selaku wakil jabatan dan disebut pemangku jabatan atau pejabat (F.R.Bothlingk,1954:32).

Setiap penggunaan wewenang oleh pejabat selalu disertai dengan tanggung jawab, sesuai dengan prinsip "deen bevoegdheid zonder verantwoordenlijkheid"

(tidak ada kewenangan tanpa pertanggungjawaban). Karena wewenang itu melekat pada jabatan, namun dalam implementasinya dijalankan oleh manusia selaku wakil atau fungsionaris jabatan, maka siapa yang harus memikul tanggung jawab hukum ketika terjadi penyimpangan harus dilihat secara kasuistik karena tanggung jawab itu dapat berupa tanggung jawab jabatan dan dapat pula berupa tanggung jawab dan tanggung gugat pribadi.

\section{2.a. Tanggungjawab Jabatan}

Berdasarkan ketentuan hukum, pejabat hanya menjalankan fungsi dan wewenang, karena pejabat tidak memiliki wewenang. Yang memiliki dan dilekati wewenang adalah jabatan. Dalam kaitan ini, Logemann mengatakan bahwa, berdasarkan Hukum Tata Negara, jabatanlah yang dibebani dengan kewajiban, yang diberi wewenang untuk melakukan perbuatan hukum.

Hak dan Kewajiban berjalan terus, tidak peduli dengan pergantian pejabat (Logemann, 1958:89). Karena kewenangan itu melekat pada jabatan, sementara tanggungjawab dalam bidang publik itu terkait dengan kewenangan, maka beban tanggungjawab itu pada dasarnya juga melekat pada jabatan. 
Tanggungjawab jabatan ini berkenan dengan keabsahan tindakan hukum pemerintahan yang dilakukan oleh pejabat untuk dan atas nama jabatan (ambtshalve). Menurut F.R. Bothlingk, baik wakil maupun yang diwakili adalah pelaku, namun tidak berarti bahwa keduanya mempunyai tanggung jawab. Berkenan dengan perbuatan hukum, jawabannya jelas. Perbuatan hukum adalah pernyataan kehendak dan tanggung jawab secara khusus tertuju kepada pihak yang kehendaknya dinyatakan, yakni pihak yang diwakili. Wakil tidak menyatakan kehendaknya sendiri, karena itu meletakan tanggung jawab kepadanya tidak pada tempatnya (F.R.Bothlingk: 1954:137).

Meskipun kewenangan itu melekat pada jabatan yang membawa konsekwensi melekatnya tanggung jawab pada jabatan yang bersangkutan, namun dapat saja dalam pelaksanaan kewenangan itu tanggung jawabnya dibebankan kepada pribadi (in persoon) pejabat.

\section{2.b. Tanggungjawab Pribadi}

Tanggung jawab pribadi berkaitan dengan maladministrasi dalam penggunaan wewenang maupun public service. Seorang pejabat yang melaksanakan tugas dan kewenangan jabatan atau membuat kebijakan akan dibebani tanggung jawab pribadi jika ia melakukan tindakan maladministrasi.

F.R.Bothlingk mengatakan bahwa pejabat atau wakil itu bertanggung jawab sepenuhnya, ketika ia menyalahgunakan situasi dengan melakukan tindakan amoralnya sendiri terhadap kepentingan pihak ketiga (F.R.Bothlingk, 1954:142). Seseorang bertanggung jawab secara pribadi terhadap pihak ketiga bilamana ia telah bertindak secara moril sangat tercela atau dengan itikad buruk atau dengan sangat ceroboh, yakni melakukan tindakan maladministrasi.

Maladministrasi berasal dari bahasa Latin malum (jahat, buruk, jelek) dan administrare (to manage, mengurus, atau melayani), Maladministrasi berarti pelayanan atau pengurusan yang buruk atau jelak. Berdasarkan pasal 1 angka (3) UU No. 37 Tahun 2008 tentang Ombudsman Republik Indonesia, yang dimaksud Maladministrasi adalah " Perilaku atau perbuatan melawan hukum, melampaui wewenang, menggunakan wewenang untuk tujuan lain dari yang menjadi tujuan wewenang tersebut, termasuk kelalaian atau pengabaian kewajiban hukum dalam penyelenggaraan pelayanan publik yang dilakukan oleh penyelenggara Negara dan pemerintahan yang menimbulkan kerugian materiil dan/atau immaterial bagi masyarakat dan orang perseorangan”.

Dalam panduan investigasi untuk Ombudsman Republik, disebutkan dua puluh macam maladministrasi, yakni penundaan atas pelayanan (berlarut-larut), tidak menangani, melalaikan kewajiban, persekongkolan, kolusi dan nepotisme, bertindak tidak adil, nyatanyata berpihak, pemalsuan, pelanggaran undang-undang, perbuatan melawan hukum, diluar kompetensi, tidak kompeten, intervensi, penyimpangan prosedur, bertindak sewenangwenang, penyalahgunaan wewenang, bertindak tidak layak/tidak patut, permintaan imbalan uang/korupsi, penguasaan tanpa hak, dan penggelapan barang bukti.

Secara ringkas dapat dikatakan bahwa setiap penyelenggaraan urusan pemerintahan yang didalamnya ada unsure maladministrasi dan merugikan warga Negara, tanggung jawab dan tanggung gugatnya dibebankan kepada pribadi orang yang melakukan tindakan maladministrasi tersebut.

Diatas telah disebutkan bahwa UU No 5 Tahun 1986 tentang PTUN dan peraturan pelaksanaannya menganut teori tanggung jawab jabatan, namun dalam perkembangannya, khususnya setelah perubahan UU PTUN No 9 Tahun 2004 tentang Perubahan atas UU No 5 Tahun 1986, dianut pula tanggung jawab pribadi. Berdasarkan Pasal 116 ayat (4) UU No 9 Tahun 2004 disebutkan bahwa, "Dalam hal 
tergugat tidak bersedia melaksanakan putusan Pengadilan yang telah memperoleh kekuatan hukum tetap, terhadap pejabat yang bersangkutan dikenakan upaya paksa berupa pembayaran sejumlah uang paksa dan/atau sanksi administratif", dan dalam ayat (5) disebutkan bahwa "Pejabat yang tidak melaksanakanputusan Pengadilan sebagaimana dimaksud pada ayat (4) diumumkan pada media massa cetak setempat oleh Panitera sejak tidak terpenuhinya ketentuan sebagaimana dimaksud pada ayat (3)". Dalam penjelasannya tidak disebutkan apakah ketentuan Pasal 116 ayat (4) dan (5) ini merupakan tanggung jawab jabatan atau pribadi, namun jika dicermati dari latar belakang dan semangat perubahan undangundang ini tampak bahwa ketentuan pasal ini dimaksudkan sebagai tanggung jawab pribadi. Dengan demikian, UU PTUN saat ini menganut tanggung jawab jabatan dan tanggung jawab pribadi. Adapun kapan tanggung jawab jabatan dan tanggung jawab pribadi itu diterapkan, tergantung pada dalam hal apa dan bagaimana perbuatan atau tindakan pemerintahan itu dilakukan.

\section{PE N U T UP}

Konsep Negara hukum dalam era modern, menunjuk pemerintah sebagai pelaksana kebijaksanaan yang merupakan suatu keharusan bagi pemerintah dalam hal melaksanakan pembatasan terhadap undangundang dan sesuai dengan kegiatan pemerintah dalam melakukan pelayanan publik ke masyarakat yang progresif. Namun dalam menggunakan kebijaksanaan tidak diperbolehkan bertentangan dengan asas-asas umum pemerintahan yang baik, khususnya asas larangan penyalahgunaan wewenang dan asas larangan sewenangwenang. Selain itu juga tidak boleh bertentangan dengan kepentingan umum.

Penyimpangan terhadap penggunaan diskresi dapat diuji melalui peradilan dan pembuat kebijakan akan dibebani tanggung jawab. Ada dua bentuk tanggung jawab, yakni tanggung jawab jabatan dan tanggung jawab pribadi. Tanggung jawab jabatan terjadi ketika pembuat kebijakan menggunakan diskresi untuk dan atas nama jabatan, sedangkan tanggung jawab pribadi diterapkan dalam hal pembuat kebijakan melakukan tindakan maladministrasi.

\section{DAFTAR PUSTAKA}

Amarullah Salim, Perbuatan Melawan Hukum Yang dilakukan oleh Penguasa Menurut Hukum

Perdata Beserta Masalah Ganti

Rugi, Bahan Kuliah Pekan Orientasi dan Penataran Peradilan Tata Usaha Negara, Jakarta, 1994

Azhary, Negara Hukum Indonesia Analisa

Yuridis Normatif tentang UnsurUnsurnya, UI-Press, Jakarta, 1995.

Arifin P. Soeria Atmadja, Keuangan Publik dalam Perspektif Hukum; Teori, Kritik, dan Praktik, Rajawali Press, Jakarta, 2008.

Bagir Manan dan Kuntana Magnar, Peranan Peraturan Perundang-undangan dalam Pembinaan Hukum Nasional, Armico, Bandung 1987. ,Peranan Hukum

Administrasi Negara dalam

Pembentukan Peraturan perundang-Undangan, Makalah pada Penataran Nasional Hukum Acara dan Hukum administrasi Negara, Fakultas Hukum Unhas, Unjung Pandang, 1996.

E. Utrecht, Pengantar Hukum Administrasi Negara Indonesia, Pustaka Tinta Mas, Surabaya, 1988. 
F. R.Bothlingk, Het Leerstuk der Vertegenwoordiging en Zijn Toepassing op Ambtsdragers in Nederland en in Indonesia, Juridische Boekhandel en Uitgeverrij A. Jongbloed \& Zoon's-Gravenhage, 1954.

Fungsinya Selaku Sarana Hukum Pemerintahan, Makalah pada Penataran Nasional Hukum Acara dan Hukum Administrasi Negara, Fakultas Hukum Universitas Hasanudin, Ujung Pandang 26-31 Agustus 1996.

Marcus Lukman, Eksistensi Peraturan Kebijaksanaan dalam bidang Perencanaan dan Pelaksanaan Rencana Pembangunan di Daerah serta Dampaknya Terhadap Pembangunan Materi Hukum Tertulis Nasional, Disertasi, Universitas Padjajaran, Bandung, 1996.

Moh. Mahfud, Politik Hukum di Indonesia, LP3ES, Jakarta, 1998

Philipus.M.Hadjon, Perlindungan Hukum Bagi Rakyat di Indonesia, Edisi Revisi, Peradaban, Surabaya, 2007.

S.F.Marbun, Pembentukan, Pemberlakuan, Dan Peranan Asas-asas Umum Pemerintahan yang Layak dalam Menjelmakan Pemerintahan Yang Baik dan Bersih di Indonesia, Disertasi, Universitas Padjajaran Bandung, 2001.
H.D.Stout, de Betekenissen van de Wet, Theoretisch-Kritische Beschouwingen over het Principe van Wetmatigheid van Bestuur, W. E. J. Tjeenk Willink-Zwolle, 1994.

Laica Marzuki, Peraturan Kebijaksanaan (Beleidsregel) Hakikat serta 